\title{
The evolving story of orexin biology: the hits keep coming
}

\section{Willis K Samson}

\author{
Address: Department of Pharmacological and Physiological Science, Saint Louis University School of Medicine, 1402 South Grand Boulevard, St \\ Louis, MO 63104, USA \\ Email: samsonwk@slu.edu
}

FI000 Biology Reports 2009, I:85 (doi:I0.34I0/BI-85)

The electronic version of this article is the complete one and can be found at: http://FI000.com/Reports/Biology/content/I/85

\begin{abstract}
In the span of just II years since their discovery, the study of the orexins (hypocretins) has not only provided insight into the biology of sleep/wakefulness, but also demonstrated the importance of the development of new pharmacologic tools and genetic models with which to understand basic physiologic mechanisms and provide potential strategies for the treatment of human pathologies. Highlights from recently published novel approaches and findings are reviewed here.
\end{abstract}

\section{Introduction and context}

Discovered almost simultaneously by two independent groups, orexin A and orexin B (also known as hypocretin-1 and hypocretin-2) are post-translational products of a gene expressed almost exclusively in neurons of the hypothalamus $[1,2]$, where functionally distinct subpopulations of orexin neurons have been hypothesized to reside [3]. Orexin neurons in the lateral hypothalamic area have been suggested to be important in hunger and reward, while those in the dorsomedial hypothalamus are more related to arousal state [3]; however, their exact roles remain open for debate [4]. Two cognate receptors have been identified, orexin type 1 receptor $\left(\mathrm{OX}_{1} \mathrm{R}\right)$, which couples primarily via a $\mathrm{Gq} / 11$, and orexin type 2 receptor $\left(\mathrm{OX}_{2} \mathrm{R}\right)$, which couples via $\mathrm{Gi}$ or $\mathrm{Gq} / 11$, and perhaps a Gs protein. In addition to their originally described orexigenic actions, the peptides act pharmacologically to increase arousal $[5,6]$, elevate sympathetic tone $[7,8]$, stimulate the neuroendocrine mechanisms controlling stress hormone secretion [9-12], and activate reward pathways [3]. However, their hallmark actions, which are clearly physiologic in nature, are related to sleep/wakefulness [13]. Compromises in the production of orexin or $\mathrm{OX}_{2} \mathrm{R}$ result in a behavioral phenotype similar to human narcolepsy/cataplexy $[14,15]$ and indeed many human cases of narcolepsy appear to be the result of selective degeneration of orexin-producing neurons in the lateral hypothalamic/perifornical area of the brain [16].

\section{Major recent advances}

The potential for therapeutic use of orexin or orexin analogs to treat the debilitating symptoms of narcolepsy has driven the study of these pluripotent peptides. In the process, much has been learned about more than simply the biology of sleep/wakefulness; many novel approaches for their study have been developed. One that cannot adequately be discussed here is the innovative use of genetic targeting of the channelrhodopsin-2 gene to orexin (hypocretin) neurons followed by optogenetic photostimulation, which resulted in clear evidence that the orexin (hypocretin)-producing neurons control the transition to wakefulness from slow wave and rapid eye movement (REM) sleep [17]. It is impossible in a brief review to cite inclusively all the outstanding manuscripts in the field. Instead, the current focus is on two or three biologic effects of the peptides, recent advances in the study of those actions, and the innovative approaches employed by investigators in the field to elucidate the full biologic spectrum and potential therapeutic uses of the orexins. For more comprehensive coverage of the subject, the readers may consult a recent, excellent review by one of the peptides' discoverers, T Sakurai [13]. 


\section{Which orexin receptor mediates the arousal effects?}

Deletion of the orexin gene results in an animal with a behavioral phenotype similar to human narcolepsy/ cataplexy [14]. Similarly, compromise of the $\mathrm{OX}_{2} \mathrm{R}$ gene [15] produces a narcoleptic/cataplectic phenotype. In normal rats, central administration of a selective $\mathrm{OX}_{2} \mathrm{R}$ ligand enhanced wakefulness while reducing REM and non-REM sleep [18]. An innovative approach to the identification of the orexin receptor subtype responsible for maintenance of wakefulness was recently employed by Shiromani and colleagues [19]. They identified $\mathrm{OX}_{2} \mathrm{R}$ expression in enhanced green fluorescent protein-positive GABAergic ( $\gamma$-aminobutyric acid-producing) neurons of the ventrolateral periaquaductal gray (vlPAG) of a transgenic animal and then targeted those neurons for destruction using a saporin hypocretin-2 (orexin B) conjugate. This not only identified the vlPAG as a potential site of action for the arousal effects of orexin, but also demonstrated the importance of the $\mathrm{OX}_{2} \mathrm{R}$ in the inhibitory control of REM sleep. Additional experiments in this excellent manuscript suggest the importance of the vIPAG in the action of the orexins is limited to REM sleep, but that it is not a substrate for the cataplexy of orexin absence.

\section{Is there hope for development of a therapeutic strategy for orexin replacement?}

In humans degeneration of orexin-producing neurons can cause narcolepsy/cataplexy [16]. Thus, the full phenotype of human narcolepsy might require loss of the orexin-producing neuron, and consequently the absence of not only orexin, but also co-localized peptides like galanin, dynorphin, or neuronal activityrelated pentraxin. For this reason Yanagisawa and colleagues developed the orexin-ataxin-3 transgenic mouse and rat models $[20,21]$, in which, over time, the orexin-producing neurons degenerate and the behavioral phenotype eventually appears. Proof that the behavior was due to the loss of orexin came in studies using these animals with subsequent central administration of high doses of orexin or ectopic expression in brain of a preproorexin transgene [22]. Thus, it appeared possible that ligands selective for $\mathrm{OX}_{2} \mathrm{R}$ might be developed that could cross the blood-brain-barrier and replace the missing endogenous orexin, rescuing the phenotype. However, with the exception of one report in nonhuman primates [23], little evidence for therapeutic penetration of peripherally administered orexin has been forthcoming.

An alternative would be gene transfer within brain. Proof of concept was recently published by Liu et al. [24]. Using a replication defective herpes simplex virus- 1 ampliconbased vector, these authors transferred the gene encoding orexin into the lateral hypothalamus of orexin knockout mice. They demonstrated transient neuronal expression and, importantly, a temporally correlated improvement of the behavioral phenotype. As the authors openly conclude, gene transfer worked in the orexin knockout mice, where orexin expression has been lost but not the orexin-producing neurons. The technique now needs to be applied to the more relevant animal model, the orexin-ataxin-3 transgenic mouse (or rat), in which the orexin-producing neurons have been lost, just as is the case for the brains of humans suffering from narcolepsy/ cataplexy.

\section{What about the opposite side of the coin? Could orexin antagonists be used to treat insomnia?} Almorexant, a dual $\mathrm{OX}_{1} \mathrm{R} / \mathrm{OX}_{2} \mathrm{R}$ antagonist has been demonstrated to act after peripheral administration to promote sleep in a variety of species, including humans [25]. Recently, Dugovic and colleagues [26] demonstrated that the effects of almorexant were in all likelihood due to the compound's ability to block $\mathrm{OX}_{2} \mathrm{R}$, as similar sleep-promoting effects (decreased latency for persistent sleep and increased non-REM and REM sleep time) were observed in rats treated with a selective $\mathrm{OX}_{2} \mathrm{R}$ antagonist.

\section{What other effects of orexin might appear during therapeutic use of agonists or antagonists of the receptors?} As mentioned already, the orexins are pluripotent neuromodulators. Two areas of current research point to impressive additional actions of the peptides. Orexin knockout mice not only demonstrate a narcoleptic phenotype, but also with aging develop obesity, which at first seems counterintuitive since the peptide pharmacologically stimulates food intake. Indeed, knockout mice eat less but gain more weight than age-matched wild-type mice. Once again, the Yanagisawa and Sakurai labs have employed state of the art genetic approaches to examine this apparent paradox [27]. They have demonstrated recently that transgenic overexpression of orexin protects against high-fat-diet-induced obesity, and the attendant insulin insensitivity, by promoting energy expenditure. Surprisingly, these mice actually ate less as well. Combining the genetic background of the orexin overexpressing transgene with either $\mathrm{OX}_{1} \mathrm{R}$ or $\mathrm{OX}_{2} \mathrm{R}$ knockout animals, these authors demonstrated that $\mathrm{OX}_{2} \mathrm{R}$ is essential for the prevention of diet-induced obesity. Leptin sensitivity was also improved in these animals. This may indicate the important interaction of metabolic cues and orexin, as might be predicted from the intriguing findings of Burdakov and colleagues [28] that orexin neurons in lateral hypothalamus respond directly to fluctuating levels of plasma and cerebrospinal fluid glucose. Thus, selective activation of $\mathrm{OX}_{2} \mathrm{R}$ in humans may not only ameliorate the sleep disturbances of orexin cell loss, but also alleviate some of the 
consequences of the metabolic-syndrome-like phenotype of many narcoleptic humans [29].

\section{Can manipulation uniquely of the $O X_{I} R$ be rewarding?}

Finally, much interest has been generated in the possibility that the orexins play an important role in reward behaviors [3]. Orexin appears to influence morphine-induced place preference [30]. A role for $\mathrm{OX}_{1} \mathrm{R}$ in reward/addictive behaviors has been demonstrated by these authors as well [3]. Antagonism of $\mathrm{OX}_{1} \mathrm{R}$, but not $\mathrm{OX}_{2} \mathrm{R}$, decreased cue-induced cocaine seeking, following extinction or abstinence [31]. Thus, one could envision the potential use of orexin antagonists for the modification of reward-based behaviors [3]. However, $\mathrm{OX}_{1} \mathrm{R}$ has also been implicated as the receptor mediating the autonomic and neuroendocrine actions of the orexins [12] and, therefore, selectivity of effect may be a difficult issue to control. The realization of the important actions of the orexins on reward-based and addictive behaviors may provide insight into the neuronal mechanisms responsible for the expression of those behaviors.

\section{Is arousal the overriding effect of the orexins or can the peptides exert biological actions independent of arousal state?}

Another way of stating the question would be: is the orexigenic action of the peptide secondary to arousal? If so, why do orexin knockout mice become obese even though they eat less? We were never overly impressed by the magnitude of food consumption observed in our ad libitum fed rats following orexin administration, but we were impressed by the sympatho-stimulatory effects of those doses and the increases in spontaneous locomotor activity that ensued $[5,6,8]$. Are the increased autonomic function and locomotor activities a reflection of activation of stress pathways in the brain [9-12]? Does activation of stress pathways initially induce and subsequently suppress food intake? It is clear from the outstanding work of Yanagisawa and colleagues [27] that "...orexin gain of function promotes energy expenditure while loss of function promotes energy conservation". As those authors speculated [27], the sympatho-stimulatory action of the orexins may partly explain those observations.

\section{Future directions}

Clearly the development of orally active orexin analogs is a goal of many investigators. However, the simple fact that the orexins are 'pluripotent' neuropeptides raises design problems that may prove daunting, if not insurmountable. While some antagonists are in development, the manipulation of central orexin levels has, to date, been limited to direct administration or transgenic delivery. Orexin analogs for therapeutic usage must have receptor selectivity especially when targeting $\mathrm{OX}_{2} \mathrm{R}$, since activation of $\mathrm{OX}_{1} \mathrm{R}$, at least in experimental animals, causes a stress response (i.e., elevated mean arterial pressure and stress hormone secretion). The promise of application of $\mathrm{OX}_{2} \mathrm{R}$ selective ligands for the treatment of metabolic syndrome is great, but again bioavailability and selectivity are major hurdles to be cleared. Will these orexin analogs be of clinical value for addiction therapies and eating disorders? Here too, selectivity will be an issue. In any case, the study of orexin biology has been and still is opening many new insights into human physiology and driving the development of novel scientific approaches.

\section{Abbreviations}

$\mathrm{OX}_{1} \mathrm{R}$, orexin type 1 receptor; $\mathrm{OX}_{2} \mathrm{R}$, orexin type 2 receptor; REM, rapid eye movement; vlPAG, ventrolateral periaquaductal gray.

\section{Competing interests}

The author declares that he has no competing interests.

\section{Acknowledgements}

The author would like to thank Denis Burdakov, KarlHeinz Herzig, and Peter Shiromani for suggestions of important recent publications to be commented upon in this article. The author receives funding from the National Institutes of Health (grant 2RO1 HL066023).

\section{References}

I. De Lecea L, Kilduff TS, Peyron C, Xao XB, Foye PE, Danielson PE, Fukuhara C, Battenberg ELF, Gautvik VT, Bartlett FS, Frankel WN, van den Pol AN, Bloom FE, Gautvik KM, Sutcliffe JG: The hypocretins: hypothalamus-specific peptides with neuroexcitatory activity. Proc Natl Acad Sci U S A 1998, 95:322-7.

2. Sakurai T, Amemiya A, Ishii M, Matsuzaki I, Chemelli RM, Tanaka H, William SC, Richardson JA, Kozlowski GP, Wilson S, Arch JRS, Buckingham RE, Haynes C, Carr SA, Annan RS, McNulty DE, Liu WS, Terrett JA, Elshourbagy NA, Bergsma DJ, Yanagisawa M: Orexins and orexin receptors: a family of hypothalamic neuropeptides and $\mathbf{G}$ protein-coupled receptors that regulate feeding behavior. Cell 1998, 92:573-85.

3. Aston-Jones G, Smith RJ, Moorman DE, Richardson KA: Role of lateral hypothalamic orexin neurons in reward processing and addiction. Neuropharmacology 2009, 56(Suppl I): I I2-2I.

4. Adamantidis A, de Lecea L: Physiological arousal: a role for hypothalamic systems. Cell Mol Life Sci 2008, 65:1475-88.

5. Hagan JJ, Leslie RS, Patel S, Evans ML, Wattam TA, Holmes S, Benham CD, Taylor SG, Routledge C, Hemmati P, Munton RP, Ashmeade TE, Shah AJ, Hatcher JP, Hatcher PD, Jones DNC, Smith MI, Piper DC, Hunter AJ, Porter RA, Upton N: Orexin A activates locus coeruleus cell firing and increases arousal in the rat. Proc Natl Acad Sci U S A 1999, 96:1091 I-6.

6. Kiwaki K, Kotz CM, Wang C, Lanningham-Foster L, Levine J: Orexin A (hypocretin I) injected into hypothalamic paraventricular nucleus and spontaneous activity in rats. Am J Physiol 2004, 286:55I-9.

7. Shirasaki T, Nakazato M, Matsukura S, Takasaki M, Kannan H: Sympathetic and cardiovascular actions of the orexins in conscious rats. Am J Physiol I 999, 277:R I780-5. 
8. Samson WK, Gosnell B, Chang JK, Resch ZT, Murphy TC: Cardiovascular regulatory actions of the hypocretins in brain. Brain Res 1999, 831:248-53.

9. Ida T, Nakahara K, Murakami T, Hanada R, Nakazato M, Murakami N: Possible involvement of orexin in the stress reaction in rats. Biochem Biophys Res Commun 2000, 270:318-23.

10. Jaszberenyi M, Bujdoso E, Pataki I, Telegdy G: Effects of orexins on the hypothalamic-pituitary-adrenal system. J Neuroendocrinol 2000, I 2: 1 174-8.

II. Russell SH, Small C], Dakin CL, Abbott CR, Morgan DGA, Ghatei MA, Bloom SR: The central effects of orexin-A in the hypothalamicpituitary-adrenal axis in vivo and in vitro in male rats. J Neuroendocrinol 200I, 13:56I-6.

12. Samson WK, Bagley SL, Ferguson AV, White MM: The hypocretin/ orexin type I receptor in brain: a role in cardiovascular control and the neuroendocrine response to immobilization stress. Am J Physiol 2007, 292:R382-7.

13. Tsujino N, Sakurai T: Orexin, hypocretin: a neuropeptide at the interface of sleep, energy homeostasis, and reward system. Pharm Rev 2009, 61:162-76.

14. Chemelli RM, Willie JT, Sinton CM, Elmquist JK, Scammell T, Lee C, Richardson JA, Williams SC, Xiong $Y$, Kisanuki $Y$, Nakazato $M$, Hammer RH, Saper CB, Yanagisawa M: Narcolepsy in orexin knockout mice: molecular genetics of sleep regulation. Cell |999, 98:437-51.

15. Willie JT, Chemelli RM, Sinton CM, Tokita S, Williams SC, Kisanuki YY, Marcus JN, Lee C, Elmquist JK, Kohlmeier KA, Leonard CS, Richardson JA, Hammer RE, Yanagisawa M: Distinct narcolepsy syndromes in orexin receptor-2 and orexin null mice Molecular dissection of non-REM and REM sleep regulatory processes. Neuron 2003, 38:7I5-30.

FI000 Factor 3.0 Recommended

Evaluated by Angela Vincent 26 Jun 2003

16. Thannickal TC, Moore RY, Nienhuis R, Ramanathan L, Gukyani S, Aldrich M, Cornford M, Siegel JM: Reduced number of hypocretin neurons in human narcolepsy. Neuron 2000, 27:469-74.

17. Adamantidis AR, Zhang F, Aravanis AM, Deisseroth K, de Lecea L: Neural substrates of awakening probed with optogenetic control of hypocretin neurons. Nature 2007, 450:420-4.

FI000 Factor 9.6 Exceptional

Evaluated by Mark Mayford II Dec 2007, Gary Aston-Jones 14 Apr 2008

18. Akanmu MA, Honda K: Selective stimulation of orexin receptor type 2 promotes wakefulness in freely behaving rats. Brain Res 2005, 1048:138-45.

19. Kaur S, Thankachen S, Begum S, Liu M, Blanco-Centurion C, Shiromani PJ: Hypocretin-2 saporin lesions of the ventrolateral periaquaductal gray (vIPAG) increase REM sleep in hypocretin knockout mice. PLoS One 2009, 4:e6346.

20. Hara J, Beuckmann CT, Nambu T, Willie JT, Chemelli RM, Sinton CM, Sugiyama F, Yagami K, Goto K, Yanagisawa M, Sakurai T: Genetic ablation of orexin neurons in mice results in narcolepsy, hypophagia, and obesity. Neuron 200I, 30:345-54.

FI000 Factor 6.4 Must Read

Evaluated by Angela Vincent 19 Sep 200I, Laurence H Tecott 22 Apr 2002

21. Beuckmann CT, Sinton CM, Williams SC, Richardson JA, Hammer RE, Sakurai T, Yanagisawa M: Expression of a poly-glutamine-ataxin3 transgene in orexin neurons induces narcolepsy-cataplexy in the rat. J Neurosci 2004, 24:4469-77.

22. Mieda M, Willie JT, Hara J, Sinton CM, Sakurai T, Yanagisawa M: Orexin peptides prevent cataplexy and improve wakefulness in an orexin neuron-ablated model of narcolepsy in mice. Proc Natl Acad Sci U S A 2004, 101:4649-54.

FI000 Factor 3.0 Recommended

Evaluated by Thomas Kodadek 15 Apr 2004

23. Deadwyler SA, Porrino L, Siegel JM, Hampson RE: Systemic and nasal delivery of orexin-A (hypocretin-I) reduces the effects of sleep deprivation on cognitive performance in nonhuman primates. J Neurosci 2007, 27:14239-47.

FI000 Factor 6.0 Must Read

Evaluated by Robert Stickgold 05 Feb 2008

24. Liu M, Thankachan S, Kaur S, Begum S, Blanco-Centurion C, Sakurai T, Yanagisawa M, Neve R, Shiromani PJ: Orexin (hypocretin) gene transfer diminishes narcoleptic sleep behavior in mice. Eur J Neurosci 2008, 28:1382-93.

25. Brisbare-Roch C, Dingemanse J, Koberstein R, Hoever P, Aissaoui H, Flores S, Mueller C, Nayler O, van Gerven I, de Haas SL, Hess P, Ciu C, Buchmann S, Scherz M, Weller T, Fischli W, Clozel M, Jenck F: Promotion of sleep by targeting the orexin system in rats, dogs, and humans. Nat Med 2007, 13:150-5.

26. Dugovic C, Shelton JE, Aluiso LE, Fraser IC, Jiang X, Sutton SW Bonaventure P, Yun S, Li X, Lord B, Dvorak CA, Carruthers NI, Lovenberg TW: Blockade of orexin-I receptors attenuates orexin-2 receptor antagonism-induced sleep promotion in the rat. J Pharm Exp Ther 2009, 330:142-5I.

27. Funato $H$, Tsai AL, Willie JT, Kisanuki Y, Williams SC, Sakurai T, Yanagisawa M: Enhanced orexin receptor-2 signaling prevents diet-induced obesity and improves leptin sensitivity. Cell Metab 2009, 9:64-76.

28. Williams RH, Alexopoulos H, Jensen LT, Fugger L, Burdakov D: Adaptive sugar sensors in hypothalamic feeding circuits. Proc Natl Acad Sci U S A 2008, 105:11975-80.

29. Nishino S: Clinical and neurobiological aspects of narcolepsy. Sleep Med 2007, 8:373-99.

30. Harris GC, Wimmer M, Aston-Jones G: A role for lateral hypothalamic orexin neurons in reward seeking. Nature 2005, 437:556-9.

FI000 Factor 6.5 Must Read

Evaluated by Angela Vincent 05 Oct 2005, Kent Berridge II Oct 2005, Achim Peters 19 Nov 2007

3I. Smith RJ, See RE, Aston-Jones G: Orexin/hypocretin signaling at the orexin I receptor regulates cue-elicited cocaine-seeking. Eur J Neurosci 2009, 30:493-503. 